\title{
The image of the dictatorship in perspective: the photographs from Fernando Lemos between 1949 and 1954
}

Quote: CRUZEIRO, Cristina Pratas. The image of the dictatorship in perspective: The photographs from Fernando Lemos between 1949 and 1954. Porto Arte: Revista de Artes Visuais. Porto Alegre: PPGAV-UFRGS, v. 22, n. 36, p.1-8, jan.jun. 2017. e-ISSN 2179-8001 DOI: http://dx.doi.org/10.22456/2179-8001.80110

\section{Translated by Ana Carolina Azevedo and Bruno Declerque}

Abstract: From the photographic productions from Fernando Lemos between 1949 and 1952 in Portugal and between 1953 and 1954 in Brazil, this article aims to reflect on the imagery carried out by the artist when he left Portugal in face of the one produced in Brazil in the years immediately posthumous to his arrival. Fernando Lemos left for Brazil in 1953, exhibiting his work at the Museum of Modern Art of São Paulo and, in 1954, at the Museum of Modern Art of Rio de Janeiro - where he showcased part of the extensive photographic production he produced in Portugal. The imagery language of these photographs - the construction of space, luminosity, overlays, etc. - demonstrates a harmony with surrealism and the artistic use of photography. But in them are also imprinted the different rhythms of life and quotidian. The fact that the artist focuses his production on the portrait, makes it the best referent to allows us to understand the impact that the migration caused in his life and in his artistic work.

Keywords: Fernando Lemos. Photography. Dictatorship. Portugal. Brazil.

At the end of the 1940's, Portugal struggled with a fascist dictatorship, beginning in 1926 and lasting through 1974. Characterized by the creation of a totalitarian state that used its coercive force in all spheres of society, and a police apparatus of espionage and political repression of the most basic rights and freedoms, it was only natural that the arts domain suffered in that period. While in other European countries the development of the avant-garde movement was largely witnessed, in Portugal, the "naturalistic taste, of a distant romantic proposal" remained in the official culture (GONÇALVES, 2004, p.13). Although the 1940s introduced "awareness of the historical moment in the Portuguese artistic life" (GONÇALVES, 2004, p.13), the activities of the "most progressive proposals and the most inventive works were seen too many times in a clandestine or despised situation" (GONÇALVES, 2004, p.13). It was in this gloomy environment that, alongside abstractionist and neo-realist currents, the surrealist proposals were developed with greater impetus in Portugal.
With similarities to the avant-garde proposals developed in other countries, especially in France (Paris), where information arrived more easily, the three trends shared the same form of relationship with the world, as Rui Mário Gonçalves stated:

"an awareness that, in our time, no country can alienate itself from the problems posed by history; with participation in the construction of a planetary language; struggling against the isolation and anachronism of Portuguese artistic culture; fighting against political isolation"(GONÇALVES, 2004, p.23).

Surrealism was founded in Paris in 1924, accompanied by the 'Surrealism Manifesto', written by André Breton. There, the poet states "So much belief is given to life, to what it has of most precarious, to the real life, that in the end this belief ends up being vain." (BRETON , 1993 , p.15). This sentence sums up one of the fundamental premises of surrealism: the precariousness of the human condition and, at the same time, the disagreement with a state of numbness in the face of life. In this perspective, the movement sought a reconstruction of society without basing itself on escaping from reality, but on the search for its absolute knowledge. Breton believed "in the future resolution of these two apparently contradictory states, which are the dream and reality, in a kind of absolute reality, of surreality" (BRETON, 1993, p.24).

As is well known, the presence of surrealism in the various areas of culture and artistic practice disseminated in several proposals both contemporary and posterior to the French movement, emerging both on the European continent and the American continent. With the end of World War II and the return of Breton and other members of the group to Paris $^{1}$, some talks were established with Portuguese artists and intellectuals. And so, at the same time of the relaunch of the movement in Paris in 1947, the surrealist movement was launched in Portugal (FRANÇA, 2000, p.49). Before that, there had been some experiments in the areas of literature and fine arts $^{2}$, with little public impact, but with great impact

1. During World War II, several members of the French Surrealist Group found themselves in the contingency of self-exile, fleeing to different countries, namely to the USA, where they disseminated and left solid seeds of surrealism.

2. These include: The publication in the 'Diário de Lisboa', on May $8^{\text {th }}, 1936$, of a text made from the automatic experiment of the cadavre-exquis made by António Pedro, Dutra Faria, Carlos Tinoco and Ramiro de Valadão (FRANÇA, 1984, p.380); a painting exhibition, carried out in 1940 by António Pedro and António Dacosta where open surrealistic influences are denoted. 
for some young artists who turned to be "the protagonists of a surrealist adventure that, somewhat organizedly, would project the preceding events" (FRANÇA, 1985, p.380).

In Portugal, taking into account the political and social context and the desire to change it, the development of surrealism "was accompanied by an awareness of the problems and contradictions that the movement raised [...]" (FRANÇA, 2000, p.49), namely "the improvisation of an attitude, even of a temporal responsibility, in the midst of the timelessness of Portuguese society" (FRANÇA, 2000, p.49). The initial group included visual artists - Marcelino Vespeira, Fernando de Azevedo, António Domingues and Moniz Pereira - the poets and writers Mário Cesariny and Alexandre O'Neill and also the art critic and historian José Augusto França. They were joined by Antonio Pedro, who was a little older than the others.

The ideological position of Surrealism in relation to the Portuguese fascist dictatorship was soon undertook. In the first exhibition from the group, held in a old studio from António Pedro and António Dacosta, in Rua da Trindade, in Lisbon, the imagery impact of the paintings competed with the impact of the catalog, whose cover was meant to have a political poster supporting the candidacy of Norton de Matos to the presidential elections and the phrase: "The Surrealist Group of Lisbon/ questions/ after twenty-two years of/ Fear/ Will we still be able / of an act of /Freedom?/ It is absolutely/ indispensable/ to vote against/ fascism" (FRANÇA, 2000, p.387). This cover, censored and refused by the Civil Government, was eventually "replaced at the last minute by a white cover hand-scratched by two strokes of a blue pencil" (FRANÇA, 2000, p.388).

Nevertheless, this collective breath of surrealism in Portugal rapidly faded. The Portuguese surrealist group had, as such, scarce public representation - due, among other reasons, to the divisions that were soon to take place in $1949^{3}$ - and soon after the exhibition, the members of the group dispersed from it. Thus, the fifties began in the country with few assumed representatives of the movement. According to José Augusto França, in 1952, Marcelino Vespeira and Fernando de Azevedo were the only ones who regularly pursued their work in the context of surrealism (FRANÇA, 2000, p.390).

3. In 1949, Mário Cesariny broke up with the Surrealist Group, creating another group, 'The Surrealists', which included, among others, Mário Henrique Leiria and Cruzeiro Seixas.
And it was then that Fernando Lemos broke into the history of surrealism in Portugal. In that same year, 1952, he participated with Marcelino Vespeira and Fernando de Azevedo in an exhibition dedicated to Antonio Pedro, declaring in the catalog that it was his "first public and responsible performance regarding any relationship to do with the surrealist movement" (ACCIAIUOLI, 2005, p.5). At Casa Jalco, a furniture and decoration house with no tradition in art exhibitions, Lemos presented his work to the public for the first time, with oil paintings, gouache paintings, drawings and photographs. Although rather unknown, his work took a prominent position in the exhibition, because one of his photographs was reproduced on the cover of the catalog, but above all because photography was still a medium to still be explored in the context of Portuguese surrealism. Still, contradicting Lemos' individual history, which, at the age of 26 , began his public career as an artist, "the Azevedo-Lemos-Vespeira exhibition was, in fact, the last possible adventure of this same modernism" (FRANÇA, 2000, p.395).

The fifty-five photographs that Fernando Lemos showcased at Casa Jalco had been taken from 1949 onwards, were framed in a broader process of artistic creation, directed to technical experimentalism and, simultaneously, to the questioning of his artistic practice in the realm of surrealism and of the social context lived in Portugal. Shortly after his exhibition, Lemos returned to showcase a selection of this photographic set, again in Lisbon, in the Galeria de Março, soon after, in 1953, emigrating to Brazil. Then, in this new social and cultural context, the artist returned to photography as an artistic medium, but for a short time and without the evidenced content of surrealism. It can be said that the photograph fills a short period (1949-1954) of the long artistic activity of Fernando Lemos. However, although they are as such, the premises contained in it, denote their importance in the artist's artistic path, as well as manifest to be of great interest for the history of art.

Intimidade dos Armazéns do Chiado was the photograph reproduced in the cover of the catalog from the exhibition from 1952, in Casa Jalco. There, a series of objects - a table with a sculpture of the personification of the dance, paint cans and other manual work tools, a series of upper limbs of mannequins hung by hooks as if they were pieces of meat in 
a butcher shop, etc. - coexisted with a head in the form of a sculptural bust. Each of the objects, as well as the spatial location of the photograph, refer to the Chiado, to the environment lived in one of the privileged places of the surrealists of Lisbon. Thus we see the fragments of mannequins, found by Mário de Almeida Camilo in one of the Grandes Armazéns do Chiado, representative of the local commerce, alongside workshop tools, representative of the workshops, and a sculpture, representative of one of the cultural activities and artistic images. All located in a space that refers to an workshop environment, by the signs of dirt on the windows and the table, as well as the squares drawn on the wall.

The "association of objects worthy of the Lautréamont of the Cantos de Maldoror" (HERKENHOFF, 2004, p.20) undoubtedly places this photograph in the imaginary lexicon of surrealism. Observe the compositional proximity of this photograph with those produced by Man Ray in 1933 for the cover of the catalog 'Photographs by Man Ray, 1920-1934', published by James Thrall Soby. In this series, also on a table, there is a series of objects with no apparent relation between them, from those that Man Ray considered to be the "objects of my affection" to others without intervention of the artist. In the photographs from the series, the presence of the woman takes place in several poses and degrees of prominence, being present in one of them only from the neck up, as in the photo Intimidade dos Armazéns do Chiado, from Fernando Lemos. Lemos's approach to Man Ray was, moreover, pointed out in 1953 , in an article in the magazine 'Plano Focal' where alongside photographs by Herbert List, Man Ray, Edward Weston, Blumenfeld and Moholy-Nagy, it was affirmed that Fernando Lemos "is one of the rare Portuguese photographers whose style and aesthetic preoccupations resemble those of Man Ray" (SENA, 1998, p.268).

Reflection on the object and its integration into artistic practice was a central concern of surrealism. Most importantly, since the 1930s, the surrealists developed several 'surrealistic objects', consisting mostly of the combination of various artifacts with originally different functions. Its function was to solve the antinomy between real and imaginary, as André Breton expressed in the 'Second Surrealism Manifesto', written in 1930, stating that "From an intellectual point of view, it was and it is about proving by all means and making recognized at any cost the artificial character of the old antinomies hypocritically destined to avoid any unpleasant agitation on the part of man [...]" (BRETON, 1993, p.127). To the surrealists "Everything leads one to believe that there is a certain point in the spirit where life and death, real and imaginary, past and future, communicable and incommunicable, high and low, are no longer apprehended contradictorily" (BRETON, 1993, p.128).

But the attempt of resolution of the antinomy between real and imaginary did not only operate through the surrealist object, but exists in other media, including photography. Intimidade dos Armazéns do Chiado is centered on this resolution, through a composition that honors the object, fragment of the real, transporting it to the plane of the imaginary, where the conjugation of elements is understood as a whole. This is what the presence of the human head in bust-object format reaffirms in the total composition.

The photographic production of Fernando Lemos has been pointed out as a purpose of his painting. The first to make this association was António Pedro, who right in the preface to the catalog of the Jalco exhibition said: "Painting with the camera or with the brushes, (Lemos) acts as one who slowly loves: discovering the millimeters and becoming tender to each discovery - reducing the enlightenment of the detail to the oblivion of everything" (FRANÇA, 1973, p.16).

Nevertheless, his photographic production reveals an experimentalism based on the reflection on the specific medium of photography. The technical issues and mechanical particularisms of photography were fundamental for the works performed by the artist in this field. If surrealists such as Man Ray tested the psychic automatism in photography through, for example, frames ${ }^{4}$, photomontages and overlaying of the negative, Lemos tested it almost exclusively by voluntarily juxtaposing two or more shots on the same film. If the techniques used by Ray took advantage the laboratory and the moment of printing on the photographic paper, Lemos's technique used the careful selection of details contemplated in the juxtapositions and later reframing and enlargement. Working with a non-automatic camera, "made it possible to take advantage of the space of a roll of 12

4. In addition to the frames, Man Ray tested several techniques from photomontage to negative overlaying. Yet, in his large photographic production, the frames, designated by Ray as 'rayographie', stand out for their innovative character. 
6X6 modules, printing several images with programmed and conscious combinations and, in the end, obtaining dozens of options to print enlarged copies of details that became entities" (LEMOS, 1994, p.159). As the artist points out, they are not mere overlays of negatives, since from them he extracted details that became the photograph itself.

Fernando Lemos tells that "In the 1940s, we, then surrealists, were very much involved with the experiences of automatic writing (which is the automatic opposite of the cameras of good behavior)" (LEMOS, 1994, p.160). His camera, a Flexaret, would not be of 'good behavior' since it had "a shutter button that was unbuttoned and loose, unautomatic, able to carry out errors from a common amateur photographer and call it a gesture operator of art in freedom [...]" (LEMOS, 1994, p.160). The relation of the artist to photography took place here, from the machine, from the exploration of what it could do. However, this relation enters into a dialectical process with the technical possibilities of photography, in particular with overlaying and framing. The different contexts in a single image, the transparencies, the textures and chiaroscuro games are achieved by exploiting a particular feature of the model of the camera the artist uses. What should be understood as a technical fragility, which would lead to the inconvenience of accidentally overlaying two photographic images, is assumed by the artist as a valence which, though consciously, may lead to the unconscious, such as automatic writing and other techniques tested by the surrealists.

The plasticity of his photographic production must be understood in this dialogue of the medium with the inquiry to his artistic production in the global. This plasticity is not what a painter uses in his painting, but that of the artist who uses the plastic characteristics of the medium he is using, in this case the "light, which is the raw material of photography" (LEMOS, 1994, p.159). Thus, his photographic production accompanied the rest of his artistic production, such as painting and drawing, being the "resolution guided by the destruction and shattering of things or parts of them without any limitation of the ways in which the painter would lead it" (ACCIAIOULI, 2005, p.8).

Despite the plasticity and the use of photography as a technical procedure framed in surrealism, both being fundamental, there is, in the photographic production of Fernando Lemos, an inescapable question: the presence of the
Portuguese dictatorial context. Moreover, the artist himself confirms it in his first exhibition, referring to:

In front of the shop windows, we saw the reflection of our daily youths threatened with repression, the distressed desires, the political dreams, the poetic daydreams and the therapies with the mannequins, so realistic and provincial in their clothes, as were we, surreally aligned in the "wheezing" cultural fabric (LEMOS, 1994, p.9).

The presence of the repressive social context, along with the desire for its liberation, being characteristic of the whole of the photographic production of Lemos, is particularly visible in the portraits made during this period. The success as a portraitist was immediate, especially in the theater media (POMAR, 1994), with "many of his originals having a wide circulation and even being edited on postcards, making him lose track of some negatives (as it has happened with the portraits of Rogério Paulo, Canto e Castro, Fernando Gusmão - and that of Almada also disappeared) " (POMAR, 1994).

Lemos photographed different personalities from the Portuguese culture and arts, especially from the Lisbon circuit, such as Marcelino Vespeira, Fernando de Azevedo, Arpad Szenes, Vieira da Silva, António Pedro, José-Augusto França, Jacinto Ramos, Glicínia Quartin, José Cardoso Pires, Jorge de Sena, Alexandre O'Neill, Alice Gomes and Adolfo Casais Monteiro. On these portraits, the artist declares that "We make portraits always with the complicity of those portrayed, that is, with the premise of not imagining them favored or humiliated, receiving light from a single lamp when it was night and from the sun (which is also only one) in the daytime operations." (LEMOS, 1994, p.160-161). But this complicity went beyond the physical aspect "to elaborate the psychological state of its characters" (Herkenhoff, 2004, p.52), in what Lemos considered to be "an affective way of doing my work as an artist with friends" and a friendly practice" determined by the quotidian itself of the cultural media of the Opposition" (POMAR, 1994).

Let us take as an example the photographs Maria Helena Vieira da Silva/ Andamento sem registro (1949-1952) and Jacinto Ramos/ Pronto para autografar (1949-1952). The two share the same compositional structure: the photographed one is presented in a close-up in double exposure, with a neutral and practically imperceptible scenery behind. In both cases, the double exposure is done in the same manner, with an image of the one portrayed in frontal position and 
another one in profile position. Note, however, that the two positions obey the same framing, the profile image being solid and 'real' and the front image ethereal and 'imaginary'. This framework is fundamental to understand the captive reading of these photographs. The position presented in a solid way looks at the infinite, at what is not there, immediately present. On the opposite side, the position presented in an atmospheric way is the frontal one, as if it was the one of the thought, of what is meant, even if muted. In a country where censorship acted in all areas and police repression acted on all those who yearned for a different society, the 'voice' of art was extremely important. And Fernando Lemos did not ignore this voice, in fact, simultaneously fulfilling the genealogical attitude of surrealism in Paris.

The framework described above is repeated in other portraits, emerging from there the subject (HERKENHOFF, 2004, p.52). In some of the photographs, the ethereal image of the portrayed person becomes the one that most challenges the viewer, either because of the position it occupies in the composition or because of the presence of a defiant look, as in Arpad Szenes/saber onde está é ficar mais perto (1949-1952). The double exposure of the subject portrayed serves then to "dynamize the pose, to deimobilize the psychological frame, to unfreeze the internal movement of the being" (HERKENHOFF, 2004, p.52). It serves to tell what does not come in a simple portrait but, at the same time, serves to contextualize the experience of this subject. Therefore, alongside the matter of double exposure, the photographs that Fernando Lemos produces from the cultural personalities of the country are united by a composition that impels a tendentiously claustrophobic sensation.

This being a matter of framing, once again, but also of lighting, the sensation of claustrophobia, of imprisonment, is achieved by the close shot on the picture, approximated to almost its total presence, with a light incidence controlled and produced by a single focus. In some cases, it is accentuated by the elimination of double exposure and its replacement by a frame that mediates the portrayed from the spectator. Example of this effect are the photographs Azevedo/ Pilar/ Vespeira/Mirar para serem vistos (1949-1952) and Maria Emília Azevedo/ Quando não há porta (1949-1952). In both cases, the frame makes it impossible to have a total visibility over the subjects portrayed, either being safe (in the first case) or pushed (in the second case) by the subjects themselves. The narrative, being allegorical, is almost immediate, tracing a continuous trajectory between the whole set of revelation of the lived atmosphere, of repression and imprisonment and, at the same time, of the will of freedom.

In addition to this issue is the fact that Fernando Lemos knows and deprives with those who are photographed. They are family and friends, though in many cases they are publicly recognized personalities. There is thus a greater complicity, which allows the artist to manipulate the subject of representation without actually manipulating it. The ambiguity of the narrative does not lie in what ones want to say, being assumed by the artist that photography, in its course in this period, fulfilled the desire to go for "an image that I lack for the discovery of a possible face of the country immersed in rhetorical traditions" (LEMOS, 2004, p.96). The ambiguity lies in not being able, with all the assertiveness, to determine if what is being told to us comes from Fernando Lemos or from each of the people portrayed or even from both. They are, in any case, "exercises of evident representation, between the real and the imaginary" (POMAR, 1994), where there is a game between the present absent and the absent present.

In Portugal, artistic photography was debated in this period with a critical reflection that, at least since the 1920 s, resisted "the new 'heresies' that combined the innovative and simple forms of the photographic frames and the documentary virtues" (SENA, 1998, p.227). Until the 1950's, photography "was made in the exhibitions, with the inspector Rosa Casaco, João da Costa Leite or Tavares da Fonseca, and also in the studio from Mestre San Payo and in the clubs like the Grupo Câmara, in Coimbra, with João Martins" (POMAR, 1994).

Still, alongside the real difficulties of implementation and the rarification of photographic products and materials, caused by World War II, "the 1950s would be a subtle exception in almost the entire photographic world. It would be a domestic and almost silent revolution, but perhaps the most rewarding one" (SENA, 1998, p.261). In the 1950's, in addition to the presence of photography in some General Exhibitions from SNBA and the production of neo-realist content by Ernesto de Sousa, some artists defined a "collective situation of rupture, also almost clandestine" such as Victor Palla and Costa 
Martins, Sena da Silva, Gérard Castello Lopes, Carlos Calvet, Carlos Afonso Dias (POMAR, 1994). The photographic production of Fernando Lemos is part of this revolution, where "a dozen people thought 'photographically'' (SENA, 1998, p.261), even though he was considered by some of his peers, from the exhibition circuits, as "an eccentric" (SENA, 1998, p.277).

It is in this context that Fernando Lemos decides to leave for Brazil. He does it in 1953 and not without carrying with himself a concrete image of Portugal, to which his photographic production showed. As an "emigrant and pre-exiled" (LEMOS, 2004, p.98) he brought with him the copies of the photographs to which he associated his "dreams and political revenge against Salazar" (LEMOS, 2004, p.98). As Lemos stated, if "the curiosity to get to know Brazil" put him "on a ship with no clue as if he would stay there", her was "certain that there would be no return" (LEMOS, 2004, p.98). The artist's words coincide with the photograph Auto-retrato Falado (1949-1952). In it, a self-portrait drawn in 1949 is glued to a brick wall, there being no scenario other than that. This association is, symbolically, that of non-return, that of the culmination of the claustrophobic environment that impelled him to change.

In Brazil the 1950s was "a more bustling period of photojournalism with the magazine $O$ Cruzeiro and later with Manchete" (HERKENHOFF, 2004, p.28). As for surrealism, few artists worked in the field of photography, "in the 1940s, Mário Pedrosa had alienated the Brazilian avant-garde from an engagement with surrealism" (HERKENHOFF, 2004, p.28). One exception would be Athos Bulcão, who from 1950 on made a considerable series of photomontages. However, "Bulcão's procedures brought him closer [...] to other Portuguese (Leiria and Vieira) than to Fernando Lemos" (HERKENHOFF, 2004, p.28).

However, the fact that Brazilian modernism "struggled understanding the modern potential of photography" (HERKENHOFF, 2004, p.28) was not an obstacle for the photographic production Lemos brought from Portugal had not been immediately received by a certain Brazilian cultural circle. In fact, as mentioned, this struggle also existed in Portugal, although it was boosted by the dictatorial regime under course, so it would not have been neutering for Fernando Lemos. Thus, the fact that at that time in Brazil there was still discussion on canons and thematic hierarchies (HERKENHOFF, 2004, p.28) did not prevent the photographic production of others, there always being artists and critics who, at the same time, assumed the aesthetic potential of the medium.

In any case, the arrival of Fernando Lemos in Brazil coincided with a greater projection of photography as art and the exhibitions he held there in 1953 and 1954 - in the São Paulo and Rio de Janeiro Museums of Modern Art ${ }^{5}$ even gave the motto to some critics for the defense of this argument ${ }^{6}$. The photographs he showcased in these exhibitions were mostly composed by the photographs produced between 1949 and 1952 in Portugal. Among them were the portraits, with the ability to transport the viewer from the 'states of soul' of the subject portrayed to the political and social environment lived in Portugal.

But the path linked to photography had not yet ended for Fernando Lemos, although in Brazil it was made of very different premises. As a photographer, "he only worked in small advertising productions or worked for friends like Lourival Gomes Machado or the writer Hilda Hilst" (MENDES, 2004, p.70), following an artistic activity mainly in painting and drawing. In 2008, as part of a guided tour to the exhibition 'Preto e Branco Fernando Lemos', in São Paulo, and referring to the photographic production made in Brazil since 1953, Fernando Lemos "reveals that no aesthetic preoccupation should be placed on this production, and that its purpose was none other than mere registration." (POMAR, 2008).

The documentary condition of these photographs does not prevent levels of comparison with the photographic productions produced in Portugal. In fact, as already mentioned, there was also a documentary condition to them. The photographs Jaime Cortesão (1954) and Mário Neme na Oca, a montage at the History Exhibition at the 4th Centenary of the Foundation og the City of São Paulo (1954) are examples of compositions where the presence of reality imposes itself on the imaginary. In the first, Jaime Cortesão, an icon

\footnotetext{
5. There he exhibits with Eduardo Anahory.

6. Wolfgang Pfeffer, in Fernando Lemos and Eduardo Anahory's Exhibition catalog, addressing the work that Lemos showcased in São Paulo in 1953, states: "There are those who consider photography a purely mechanical medium in the service of the sciences or advertising, but we can see, by the creations of photographers like Fernando Lemos, that by using the same medium it is possible to give spiritualized interpretations to objects and forms. What is undoubtedly a work of creation" (HERKENHOFF, 2004, p.34).
} 
of the Portuguese intelligentsia linked to the opposition to the fascist regime and also exiled in Brazil, does not appear alone, as in the portraits made in Portugal. In 1954, as coordinator of the Exhibition of History of São Paulo - Cortesão invited Fernando Lemos to collaborate in it - the intellectual appears integrated into a group that sings, plays instruments and laughs, in a serene, fraternal and, above all, free atmosphere. The second photo shows Mário Neme and was produced in a period close to the previous one, since the Brazilian intellectual was photographed in the context of the assembly of the exhibition coordinated by Cortesão. Here we also have a distinct composition, where Neme, in a more spontaneous and relaxed pose, is mediated by the glass of a window. This glass, adding plastic interest to the image, does not lead to any claustrophobic sensation, as in the case of photographs with the frame over the portrayed ones.

The technique that inscribed Fernando Lemos in the surrealism, in particular the one that allowed the double exposure of the portrayed one, does not exist in any of the ones mentioned, which contributes to the manifestation of the use of the photograph as a document of a moment that is one wishes to perpetuate. The artist no longer used this technique, even in staged pictures like Hilda Hilst (1954) and Lygia Fagundes Telles (1954), where there is an approach to the framing used in pictures taken in Portugal. In addition to the non-existence of the phantasmagoric duplications of the portrayed, the projected shadows, the reflections and the light incidence are also treated differently, being more open and luminous.

While the poetic intent of the photographic collections in Portugal and Brazil must be taken into account, there is a whole political and social context that shapes them, which is reflected in the very aesthetic options that Lemos took. Thus, it can be said that there is a politicized attitude that fulfills and embraces these same options. In the Portuguese context, if the 1950s were, as Rui Mário Gonçalves called it, the "decade of silence" (GONÇALVES, 2004, p.39), the photographic work of Fernando Lemos was able to oppose it. The "persistent silencing" (GONÇALVES, 2004, p.40) of Salazar's fascist dictatorial regime only had its definitive death certificate in 1974, with the April Revolution. But during its entire period it was fought by resistant anti-fascists in different domains of society. In the arts, there have been important impulses throughout the decades, especially those of neo-realism and surrealism. Lemos' photographic production, especially the portraits, are part of this history of resistance in the arts. And this is even clearer when compared to the portraits made in Brazil, a country then still at liberty.

\section{REFERENCES}

ACCIAIUOLI, M. Fernando Lemos. Lisboa: Editorial Caminho, ISBN: 972-21-1694-0.

BRETON, A. (1993) Manifestos do Surrealismo. Lisboa: Edições Salamandra, 2005. ISBN: 972-689-075-6.

FRANÇA, J.A. A Arte e a Sociedade Portuguesa no Século XX (1910-2000). Lisboa: Livros Horizonte, 2000. ISBN: 972-24-1110-1.

A Arte em Portugal no Século XX. Amadora: Livraria Bertrand, 1985.

. 'Vinte (e um) anos depois de dez dias de Janeiro de 1952'. Colóquio Artes, n. 12, 2. a série, Abril, 1973, p.14-25.

GONÇALVES, R. M. Vontade de Mudança - Cinco décadas de artes plásticas. Lisboa: Editorial Caminho,2004. ISBN: 972-21-1621-5.

HERKENHOFF, P. 'Fernando Lemos: Fotografia'. In Moura, D. (coord.) À sombra da Luz, Fernando Lemos, À luz da Sombra. São Paulo: Pinacoteca do Estado de São Paulo, 2004, p.15-67.

LEMOS, F. 'Biografia I'. In Moura, D. (coord.) À sombra da Luz, Fernando Lemos, À luz da Sombra. São Paulo: Pinacoteca do Estado de São Paulo, 2004, p.96. . 'Dedicatória'. In Lemos, F. et al. Fernando Lemos, À sombra da luz. Lisboa: Fundação Calouste Gulbenkian Centro de Arte Moderna, José de Azeredo Perdigão, 1994, p.9. . 'Depoimento 2'. In Lemos, F. et al. Fernando Lemos, À sombra da luz. Lisboa: Fundação Calouste Gulbenkian Centro de Arte Moderna, José de Azeredo Perdigão,1994, p.159.

. 'Depoimento 3'. In Lemos, F. et al. Fernando Lemos, À sombra da luz. Lisboa: Fundação Calouste Gulbenkian Centro de Arte Moderna, José de Azeredo Perdigão, 1994, p.160. . 'Depoimento 4'. In Lemos, F. et al. Fernando Lemos, À sombra da luz. Lisboa: Fundação Calouste Gulbenkian Centro de Arte Moderna, José de Azeredo Perdigão, 1994, p.160.

MENDES, R. 'Imagens Teimosas: Novamente Fernando Lemos'. In Moura, D. (coord.) À sombra da Luz, Fernando Lemos, 
À luz da Sombra. São Paulo: Pinacoteca do Estado de São Paulo, 2004, p.69-74.

POMAR, A. 'Tempo de Fantasmas'. In Expresso Revista 23 de Julho de 1994, p.60-64. Alexandrepomar. 1994. [Consult. 2017-09-13] Disponível em <URL:http://alexandrepomar. typepad.com/alexandre_pomar/2008/05/fernandolemos-1952-1994.html

_. [Consult. 2017-09-13] Disponível em <URL:http:// alexandrepomar.typepad.com/alexandre_pomar/2008/06/ fernando-lemos-no-brasil.html SENA, A. História da Imagem fotográfica em Portugal - 18391997. Porto: Porto Editora, 1998 ISBN: 972-0.06265-7.

Cristina Pratas Cruzeiro: Is a postdoctoral fellow by the FCT with the project "Collaboration and Collision: the public and political intervention of art" at the Institute of Art History of the Faculty of Social Sciences and Humanities of the Nova University of Lisbon and an invited professor at the Faculty of Fine Arts of the University of Lisbon. She is an integrated researcher at IHA-FCSH and invited researcher at CIEBA - FBAUL, Lisboa, Portugal.

(*) Text sent in 2017. 